\title{
パラメータの不確定性を考慮した動的構造信頼性評価 DYNAMIC STRUCTURAL RELIABILITY EVALUATION CONSIDERING PARAMETER UNCERTAINTIES
}

\author{
趙 衍 剛*, 小野徹 郎**, 鈴木 誠*** \\ Yangang ZHAO, Tetsuro ONO and Makoto SUZUKI
}

\begin{abstract}
In evaluating dynamic reliability of structures with consideration of uncertainties included in structural properties and excitation characteristics, the gradients of the conditional failure probability with respect to the uncertain parameters are needed. In this paper, in order to avoid the difficulties in obtaining the gradients, a procedure of extensive FORM combined with Response Surface Approach is proposed, in which the performance function is approximated by a second order response surface and solved by FORM. The influences of parameter uncertainties are discussed and it has been proved through some examples that the proposed method has advantages in both computational efficiency and precision.
\end{abstract}

Keywords: dynamic structural reliability, parameter uncertainty, FORM, performance function, response surface approach 動的構造信頼性, パラメータの不確定性, 一次信頼性評価法, 限界状態関数, 応答曲面法

1.はじめに

静的構造信頼性を評価するとき, 構造物の力学モデルのパラメー 夕, 例えば強度, 剛性などは基本確率变数に含まれ, その不確定性 は当然考慮すべきものとしている。動的構造信頼性評価では, 不規 則振動解析及び最大応答分布の同定が複雑であるため, それらの力 学モデルのパラメータはもとより, 動的解析に関わる隇衰定数, 荷 重プロセスの周波数スペクトル，継続時間などのパラメー夕も一般 に既知あるいは確定值と仮定されている。しかし、これらのパラ メータに含まれている不確定性は動的構造信頼性の評価結果に大き な影響を与える。確率過程と不規則振動論に関する研究が著しく発 展を遂げており，動的構造信頼性評価は実用的段階に至っている今 日，これらの不確定性を考慮して，適切に動的構造信頼性を評価す ることは大きな課題である[1] [5]。

本論文では，限界状態関数をResponse Surfaceで近似することによ り現在用いられる拡張FORMにおける感度解析の問題を避け, 既存 の動的信頼性解析プログラムを用いて，パラメータの不確定性を考 慮できる動的信頼性の簡便な評価法を提案した。いくつかの数值解 析例を通して, 提案した手法の特徴を考察し，その有効性を示し た。

* 名古屋工業大学 助手・工博

**名古屋工業大学 教授. 工博

*** 清水建設俐和泉研究室 主任研究員・工博

\section{2. 拡張FORMとその問題点}

パラメータ $\mathbf{X}_{1}$ を有する構造物にパラメータ $\mathbf{X}_{2}$ を有する動的荷重フ ロセス $S\left(t, \mathbf{x}_{2}\right)$ が作用する場合を考える。このとき， $\mathbf{X}=\left(\mathbf{x}_{1}, \mathbf{x}_{2}\right)$ を時 間的に変化しない確率变数と仮定すると，構造物の破壊確率は次式 で表される。

$$
P_{F}=\int_{G(\mathbf{X}, \mathbf{R}) \ll 0} f(\mathbf{X}, \mathbf{R}) d \mathbf{X} d \mathbf{R}
$$

ただし， $f(\mathbf{X}, \mathbf{R})$ は $\mathbf{X}$ と $\mathbf{R}$ 結合確率密度関数であり,$G(\mathbf{X}, \mathbf{R})$ は構造シ ステムの限界状態関数である。 $\mathbf{R}$ は不規則振動の応答变数であり， $\mathbf{X}$ の関数である。

式(1)を解くためには， $f(\mathbf{X}, \mathbf{R})$ と $G(\mathbf{X}, \mathbf{R})$ を陽な式で記述する必要が ある。しかし，一般的にこれらを陽な式で表現できることは稀であ るため, 式(1)を解くことが困難となっている。そこで, $\mathbf{X} か ゙$ 確定值 である場合の条件付き破壊確率 $P_{f}(\mathbf{X})$ を求め, 次式のようにXの全定 義領域で積分することにより全破壊確率を求める。

$$
P_{F}=\int_{\mathbf{X}} P_{f}(\mathbf{X}) f(\mathbf{X}) \mathrm{d} \mathbf{X}
$$

式(2)の解析手法としては数值積分法とMonte-Carlo法が挙げられる が, 数多くの条件付き破壊確率 $P_{f}(\mathrm{X})$ を繰り返して計算しなければな 
らない。また，2次モーメント法により解析することもできるが， $P_{f}(\mathbf{X})$ の 2 階導関数が必要となり，精度もよくない。

Madson ${ }^{[1]}$, Balendra ${ }^{[3]}$ などは補助確率变数を導入し, 動的信頼性を 等価な静的信頼性に変換して解析することを試みたが, 補助確率変 数の分布を求めることが困難であった。この問題点を解決するた め, Wen ${ }^{[1]}$ は直接標準空間で次の限界状態関数を提案している。

$$
G_{\mathbb{U}}\left(\mathbb{U}, u_{n+1}\right)=u_{n+1}-\Phi^{-1}\left[P_{f}\left\{T^{-1}(\mathbb{U})\right\}\right]
$$

ただし，UはXから変換した標準正規確率変数べクトルであり， $u_{n+1}$ は標準正規確率变数である。TはRosenblatt変換である。

さらに，䞻，小野ら ${ }^{(4) \mid[\mid} \mid$ は式(4)，(5)に示す一般的な限界状態関数を 得ており，式(3)が式(5)の特殊な形式であることも明らかにしてい る。

$$
\begin{aligned}
& F_{x_{n+1}}(0 \mathbb{X})=P_{f}(\mathrm{X}) \\
& G\left(\mathrm{X}, x_{n+1}\right)=x_{n+1}
\end{aligned}
$$

$x_{n+1}$ の導関数は次式で表される。

$$
\left\{\frac{\partial x_{n+1}}{\partial u_{i}}\right\}_{i \leq n}=-\llbracket J_{n}^{-1} \rrbracket^{T}\left\{\frac{\partial P_{f}(\mathrm{X})}{\partial x_{i}}\right\}_{i \leq n}
$$

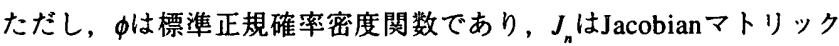
スである。

式(3)＼cjkstart式(6)には補助確率変数 $x_{n+1}$ の確率分布が含まれておらず, 結果的にFORMで式(2)を解くことができる。この手法は, FORMの 適用䉇囲をパラメー夕の不確定性を考慮した動的構造信頼性問題に 拡張しており。ここでは拡張FORM と呼ぶ。

拡張FORMでは式(6)のように限界状態関数または条件付き破壊確 率の導関数を計算することが必要となる。しかし，動的楎造信頼性 解析には固有解析, 応答解析, 不規則振動解析などの複雑な計算過 程が含まれており，その導関数を求めることは容易ではない[6]。

一方, 複雑な陰関数の取り扱い方としてはResponse Surface Approachが開発されている[7][1]。Response Surface Approachは，複雑な 陰関数を未定係数を含む簡単な陽関数で近似し，その導関数を取り 扱う上の困難さを回避する手法である。

\section{3. 解析手法}

\subsection{Response Surface Approachの概念}

複雑な椿造物の信頼性評価するとき，構造システムの限界状態関 数Zは，数多くの入力变数 $\mathbb{X}$ の関数 $Z=G(\mathbb{X})$ で表される，しかし，こ の関数は一般にかなり複雑で，陽な式で記述できないこともあり， 構造信頼性解析に大きな支障となる。そこで， $G(\mathbf{X})$ をある陽な形 式, $G^{\prime}(\mathbf{X})$ で近似し，構造信頼性解析を行うことがResponse Surface Approachの基本概念である ${ }^{[7]-[11] 。}$

一般には， $G(X)$ を末定係数を含むn次多項式 $G^{\prime}(\mathbb{X})$ で近似し， $G^{\prime}(\mathbb{X})$ に含まれている未定係数を求めるためには，選択された複数の 点 $\mathrm{X}_{i} て ゙ G\left(\mathrm{X}_{i}\right)$ を計算する（数值実験）必要がある。 $G^{\prime}(\mathrm{X})$ の次数が高 ければ高いほど $G(\mathrm{X})$ を近似する精度は高くなるが, 計算時間は多項 式の次数の増加に従って指数的に增加する。そのため, 計算精度と 計算時間のバランスを考えて，ほとんどの研究では 2 次多項式を用 いている。

$$
G^{\prime}(\mathrm{X})=a+\mathrm{X}^{T} \mathrm{~B}+\mathrm{X}^{T} \mathrm{CX}
$$

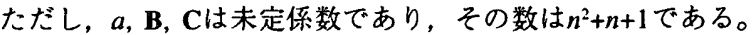

信頼性解析に対しては，設計点あるいは結合確率密度の高い点の まわりに $G(\mathrm{X})$ を精度良く近似する必要がある。しかし，限界状態関 数の陽な式についての情報が事前に分からないため, 数值実験は一 般に確率変数の平均值を中心点にして実行する。

得られた $G(\mathbf{X})$ の設計点をそのまま $G(\mathbf{X})$ の設計点として近似的に取 り扱うのは基本的な方法である。最近では精度をあげるために，次 式で新中心点を推定し, 続いてResponse Surface Approachを行うこ とも提案されている ${ }^{[9 \mid[10]}$ 。

$$
\mathrm{X}_{M}=\mu+\left(\mathbb{X}_{D}-\mu\right) \frac{G(\mu)}{G(\mu)-G\left(\mathrm{X}_{D}\right)}
$$

ただし， $\mu$ は平均值ベクトルであり， $\mathbf{X}_{D}, \mathbf{x}_{M}$ はそれぞれ得られた設計 点と移したい新中心点である。

\section{2 パラメータの不確定性を考慮した動的信頼性評価法}

本論文はResponse Surface Approachの概念をパラメータの不確定 性を考慮した動的信頼性評価に応用する。

式(3)の限界状態関数は次式で表される。

$$
G=u_{n+1}-\Phi^{-1}\left[P_{f}(\mathbf{X})\right]
$$

式(9)を次式で近似する。

$$
G^{\prime}=u_{n+1}+a+\sum_{i=1}^{n} b_{i} x_{i}+\sum_{i=1}^{n} c_{i} x_{i}^{2}
$$

ただし $, x_{i}, i=1, \cdots, n$ は基本確率変数であり， $a, b_{i}, c_{i}$ は未定係数で ある。

式(10)の中の未定係数を決めるためには， $(2 n+1)$ 個の数値実験を行 う必要がある。Fig.1に示すように確率変数の平均值を中心点とし， 中心点から $\delta_{i}$ の距離を有する各座標軸にある点 $x_{i}=\mu_{i} \pm \delta_{i}$ を実験点 とする。ただし， $\delta_{i}$ は中心距離で， $\mu_{i}$ は確率变数 $x_{i}$ の平均值である。 数值実験から $(2 n+1)$ 個の連立線形方程式が得られる。この連立線形 方程式を解くことにより式(10)は既知となり，FORMで簡単に解析 できる。

ここでは要求された収束精度に従い, 上述の計算過程をさらに信

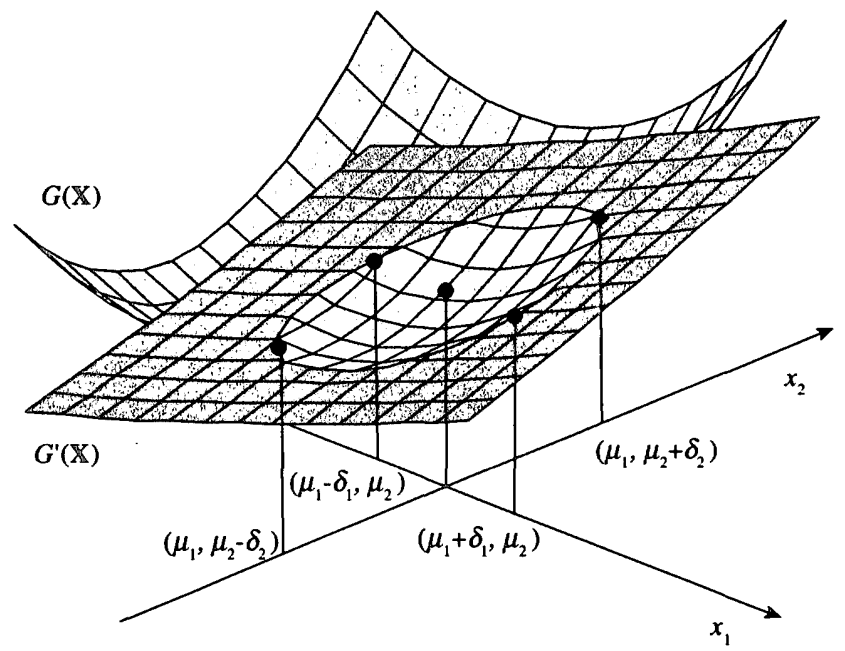

Fig.1 Location of Experimental Points for Two Variable Problem 
頼性指標の収束まで繰り返す。得られた信頼性指標はFORM信頼性 指標であり，限界状態関数が強い非線形を有する場合には精度を向 上する必要がある。そのときには，限界状態関数を 2 次関数で近似 しているため, SORMや重点サンプリングを用いて信頼性の精度を 向上することは容易となる。

上述のプロセスはFig.2に示されている。その中に，(1)条件付き破 壊確率の計算, (2)Response Surface 係数の算定, (3)FORM信頼性解 析，および(4)SORM精度向上の，4つのステップを含んでいる。

(1)条件付き破壊確率の計算では与えられた $2 n+1$ 個の実験点につい て確定的に行われ，既存信頼性解析プログラムを利用する。(2)Response Surface 係数の計算では数值実験から得られたデータより連立 線形方程式を求め, 式(10)の未定係数を決める。(3)FORMの部分で は導関数の計算はあるが, 既に得られた 2 次関数で表す限界状態関 数を対象としているため（その導関数は式(10)の未定係数から直接 計算する)，式(6)に示すような $P_{f}(\mathbf{X})$ の導関数の計算は回避されてい る。(4)SORM精度向上では式(10)の未定係数から 2 階導関数を直接 算出し, 文献[12]に示す簡単な式より計算する。このプロセスの収 束は論理的に証明されていないが，筆者らの計算経験ではほとんど の場合では $3 \sim 7$ 回の繰り返しで精度良く収束している。

\section{4. 数值解析結果}

\subsection{1 自由度線形システム}

まず，動的荷重が作用する 1 自由度線形システムの簡単な動的信 頼性問題川を通して本手法の有効性について考察する。入力はホワ イトノイズで, 荷重の強度, 継続時間, 固有振動数, 減衰定数は相 互独立的確弯变数とし，その分布をTable 1に示すように仮定する。

Table 1 Parameter Uncertainties in the 1st Example

\begin{tabular}{|c|c|c|c|}
\hline パラメータ & 分布 & 平均値 & 変動係数 \\
\hline$s$ & 極值 2 型 & 0.25 & 0.60 \\
\hline$D$ & 対数正規 & 10 秒 & 0.3 \\
\hline$f$ & 正 規 & $2 \mathrm{~Hz}$ & 0.1 \\
\hline$\zeta$ & 対数正規 & 0.02 & 0.4 \\
\hline
\end{tabular}

破壊確率をある限界值に対する初期通過確率とし, 不規則振動解 析により，各パラメータが確定值の場合の破壊確率は近似的に次式 で計算される。

$$
\begin{gathered}
P_{f}=1-\exp \left\{-f D \exp \left[-\frac{1}{2}\left(\frac{d}{\sigma_{r}}\right)^{2}\right]\right\} \\
\sigma_{r}=\sqrt{\frac{\pi s}{4(2 \pi f)^{3} \zeta}}
\end{gathered}
$$

ただし，sは入力のパワースペクトル密度，Dは継続時間， $f$ は固有振 動数，〈は隇衰定数である。

ここでは， $s, D, f, \zeta に$ 含まれている不確定性を考慮して信頼性解析 を行う。 $d=0.34$ の時, 得られた 3 回の繰り返しのResponse Surface と して，限界状態関数は次のようになる。

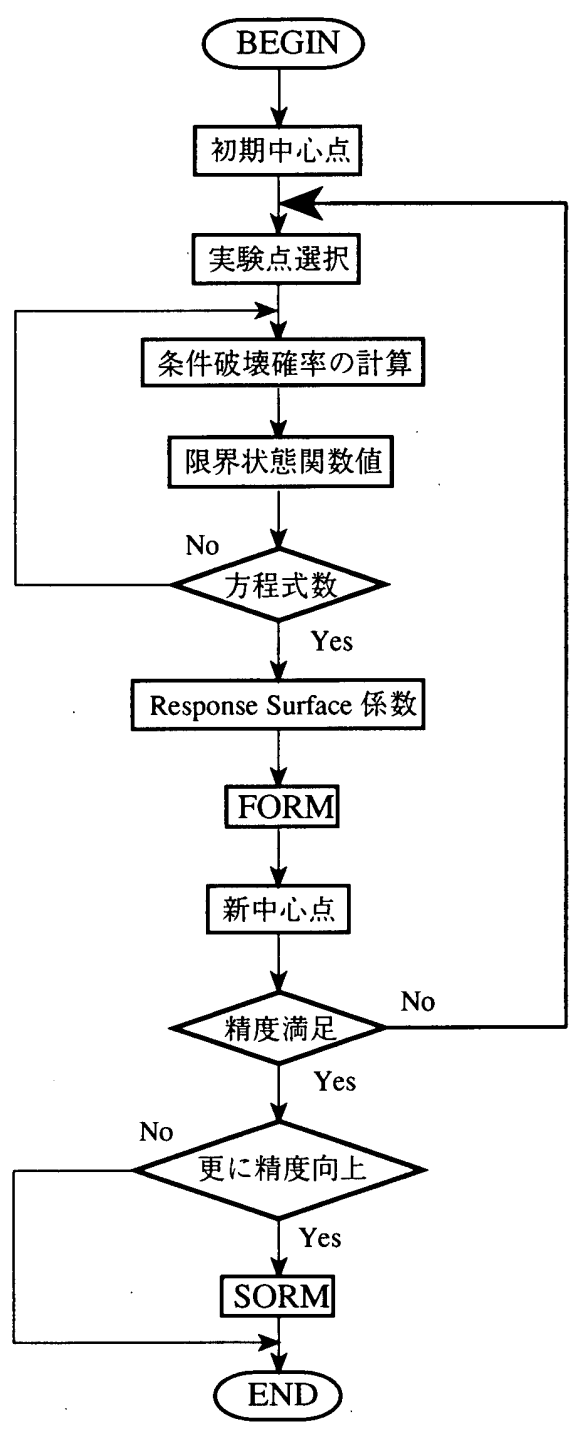

Fig.2 Flow-Chart of Response Surface Approach Used in the Dynamic Reliability Evaluation With Consideration of Parameter Uncertainties

$$
\begin{gathered}
G_{1 s t}^{\prime}=u_{n+1}-6.252+6.039 f+292.65 \zeta-28.41 s-0.053 D \\
-0.345 f^{2}-3304.5 \zeta^{2}+30.85 s^{2}+0.00127 D^{2} \\
G_{2 n d}^{\prime}=u_{n+1}-13.87+10.89 f+535.96 \zeta-17.67 s-0.119 D \\
\quad-1.605 f^{2}-10696 \zeta^{2}+11.68 s^{2}+0.00262 D^{2} \\
G_{3 r d}^{\prime}=u_{n+1}-14.01+10.76 f+549.79 \zeta-16.67 s-0.126 D \\
\quad-1.558 f^{2}-11155 \zeta^{2}+10.30 s^{2}+0.00279 D^{2}
\end{gathered}
$$

対応する各繰り返しで得られた主な計算結果をTable 2に示す。Table 2 によると, 初期中心点はその限界状態関数値 $G\left(\mathbf{X}_{0}\right)$ が 3.4 とっってお り, 真の限界状態曲面上からはかなり離れている。しかし, Response Surface の設計点は対応する限界状態関数値 $G\left(\mathbf{X}_{0}\right)$ が-0.067 なっており, 真の限界状態曲面にかなり近づいている。3 回の繰り 返しのあと, Response Surfaceの設計点はほほ限界状態曲面にあり $\left(G\left(\mathbf{X}_{0}\right)=1.7 \times 10^{-4}\right)$ ，理想的な精度（(1.61401-1.61445)/1.61401 $\left.=2 \times 10^{-4}\right)$ で収束している。最終結果としての設計点は $f=1.878$, $s=0.344, D=9.946, \zeta=0.014$ であり, 式(9)で得られた $G(\mathbf{X})$ と式(10)で 
Table 2 Main Results of Each Iteration

\begin{tabular}{|c|c|c|c|c|c|c|}
\hline $\begin{array}{l}\text { Iter. } \\
\text { No. }\end{array}$ & $\begin{array}{c}\text { Central } \\
\text { Point } \\
\mathbf{X}_{0}\end{array}$ & $G\left(\mathbb{X}_{0}\right)$ & $\begin{array}{c}\text { Design } \\
\text { Point } \\
\mathbf{X}^{*}\end{array}$ & $G^{\prime}\left(X^{*}\right)$ & $\mathbf{G}\left(\mathbb{X}^{*}\right)$ & $\begin{array}{l}\beta \\
P_{F}\end{array}$ \\
\hline $1 \mathrm{st}$ & $\begin{array}{c}2.0 \\
0.02 \\
0.25 \\
10 \\
0\end{array}$ & 3.400 & $\begin{array}{c}1.859 \\
0.014 \\
0.332 \\
9.747 \\
-0.741\end{array}$ & $8.9 \times 10^{-}$ & -0.067 & $\begin{array}{r}1.650 \\
0.0495\end{array}$ \\
\hline 2nd & $\begin{array}{l}1.862 \\
0.014 \\
0.331 \\
9.769 \\
-0.727\end{array}$ & $4 \times 10^{-4}$ & $\begin{array}{c}1.880 \\
0.014 \\
0.346 \\
9.926 \\
-0.619\end{array}$ & $1.9 \times 10^{-4}$ & $1.1 \times 10^{-3}$ & $\begin{array}{c}1.614 \\
0.0533\end{array}$ \\
\hline 3 rd & $\begin{array}{c}1.887 \\
0.014 \\
0.352 \\
9.960 \\
-0.575\end{array}$ & 0.028 & $\begin{array}{c}1.878 \\
0.014 \\
0.344 \\
9.946 \\
-0.621\end{array}$ & $1.5 \times 10^{-4}$ & $1.7 \times 10^{-4}$ & $\begin{array}{c}1.614 \\
0.0532\end{array}$ \\
\hline
\end{tabular}

Table 3 Comparison of Response Surface

\begin{tabular}{|c|c|c|c|}
\hline $\mathrm{X}=\left[f, \xi, s, D, u_{n+1}\right]$ & $\mathbb{X}-\mathrm{X}^{*} \mid$ & $G(\mathrm{X})$ & $G^{\prime}\left(\mathrm{X}^{*}\right)$ \\
\hline $1.878,0.014,0.344,9.936,-0.621$ & 0 & $1.7 \times 10^{-4}$ & $1.5 \times 10^{-4}$ \\
$1.900,0.018,0.365,9.543,-0.728$ & 0.175 & 0.728 & 0.695 \\
$1.930,0.018,0.344,9.946,-0.621$ & 0.003 & 0.139 & 1.113 \\
$1.878,0.014,0.344,9.330,-0.621$ & 0.380 & 0.345 & 0.351 \\
$1.799,0.012,0.344 .10 .41,-0.634$ & 0.220 & -0.890 & -0.871 \\
$1.600,0.013,0.344,11.30,-0.621$ & 1.910 & -1.733 & -1.809 \\
$1.630,0.016,0.423,12.80,-0.840$ & 8.260 & -2.000 & -1.880 \\
\hline
\end{tabular}

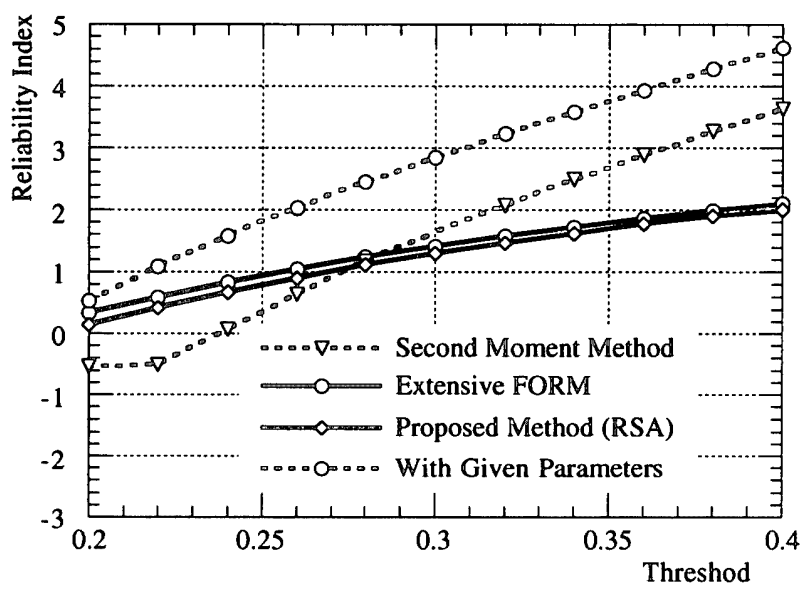

Fig.3 Reliability Index in 1st Example

得られた $G^{\prime}(\mathbb{X})$ をTable 3に示す。Table 3 により $G^{\prime}(\mathbb{X})$ は設計点のまわ りで $G(\mathrm{X})$ と精度良く一致していることがわかる。

また, 2 次モーメント法, 拡張FORMおよび本手法である Response Surface Approach を用いた結果及びパラメー夕の不確定性を 無梘した結果をFig.3に示す。Fig.3では横軸は閾値であり，縦軸は信
頼性指標である。Fig.3 から本手法は良い精度で拡張FORMの結果を 追従していることがわかる。

\section{2高䚄鉄骨骨組の地覀信頼性評価}

第 2 種地盤にある15階建，高さは52.5mである高層鉄骨骨組を対象 とする。棈造モデルを多自由度せん断型モデルとし，復元力モデルを バイリニアモデルとした。各階の階高, 重量, 初期剛性および降伏強 度をTable 4に示し, 各階の減衰定数及び剛性比を0.02,0.05にした。 構造物の非線形不規則振動解析は，平均值応答スペクトルを利用した 等価線形化解析手法[13][14][15]を用いた。この手法では，最大変位応答 までのあらゆる割線剛性の平均值を等価線形剖性と定義し，モード法 より不規則振動の応答を求める。各モードのスペクトルモーメントは 直接平均值応答スペクトルから得られ，繰り返しにより最大応答の平 均值及び標準偏差を計算する。文献[13][14]の検討により十分な計算 精度を有している。

信頼性解析に用いる破壤確率は最大応答がある限界值に対する初期 通過確率と定義し，限界塑性率は文献[16]の銅棈造骨組の変形能力を 参考にして7と仮定した。最大応答分布は次式で近似的に表される。

$$
F_{R}(u)=\exp \left\{-v D \exp \left[-\frac{1}{2}\left(\frac{u}{\sigma_{R}}\right)^{2}\right]\right\}
$$

ただし，vは0を交差する交差率(Cross Ratio)であり， $\sigma_{R}$ は不規則振動 解析から得られた応答の標準偏差である。

計算を簡素化するため, 地震動は定常Gaussian確率過程と仮定し, 地震入力は日本建築学会建築物荷重指針の加速度スペクトルは17を採 択し，そのパラメー夕を同指針の推奖值である $f_{A}=2.5, f_{V}=2.5, d=0.5$, $G_{A}=1.2, G_{v}=2.0, T_{C}=0.55$ と定めた。

1995年1月17日兵庫県南部地震で得られた最大記録の $818 \mathrm{gal}$ を地震 動最大加速度として入力し, Table 4に示している構造物のパラメー 夕をすべて確定値とした。非線形不規則振動解析の結果としての最大 層間変位 $R_{\text {max }}$ の平均値, 標準偏差および最大層間変位に対応する塑性 率と標準偏差もTable 4に示す。これらの結果により，818galの入力 ですべての階が降伏したことが分かる。最大塑性率は5階で生じてお ク，限界塑性率に対応する初期通過確率は $1.7 \times 10^{-2}$ である。

初期剛性と降伏強度に含んでいる不確定性を考虑するために，初期 剛性と降伏強度の值に平均值が 1 の確率変数を乗じる。

$$
\begin{aligned}
& \mathbb{K}_{0}^{\prime}=x_{1} \mathbb{K}_{0} \\
& \mathbb{Q}_{0}^{\prime}=x_{2} \mathbb{Q}_{0}
\end{aligned}
$$

ただし， $x_{1} ， x_{2}$ は平均值が 1 の対数正規分布に従う確率変数である。 $\mathbb{K}_{0}, \mathbb{Q}_{0}$ は確定的初期剛性と降伏強度であり， $\mathbb{K}_{0}^{\prime}$, $\mathbb{Q}_{0}^{\prime}$ は不確定性を含ん でいる初期剛性と降伏強度である。銅構造部材のヤング率（変動係数 $\mathrm{COV}=0.05)$, 降伏応力度 $(\mathrm{COV}=0.12)$, 初期たわみ $(\mathrm{COV}=0.6)$, 残留 応力度 $(\mathrm{COV}=0.5)$, 寸法 $(\mathrm{COV}=0.12)$ などの統計結果 ${ }^{[181}$ 参考にし て, 初期剛性と降伏強度の変動係数はそれぞれ0.1，0.2 と仮定する。

本手法を用いて初期剛性と降伏強度に含んでいる不確定性を考慮し た棈造信頼性を評価する。各確率変数の平均値を中心点の座標とし，

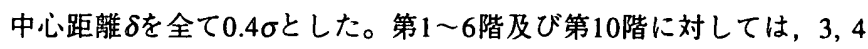
回の繰り返しで収束しているが，他の階に対しては実験点での条件付 
き破壊確率 $P_{f}(\mathbf{X})$ が0となるので解析ができない。これは, 拡張 FORMが条件付き破壊確率 $P_{f}(\mathbf{X})$ の計算とFORMのアルゴリズムに基 づいており，P(X)が0または0に近い值になる時（Table 4では, 7,8, 9階に対して中心点でのP $(\mathbf{X})$ は $10^{-7} く$ らいである），標準正規分布の 逆関数の計算が不可能となるためである。

各階の初通過に対応する破壊確率をTable 4 に示す。表中 $P_{F}$ は破壊 確率であり， $\beta$ は $P_{F} に$ 対応する信頼性指標である。Xは解析不可能を 表す。パラメータの不確定性を考慮した破壊確率は, 確定的なパラ メータの場合と比べて10倍以上大きくなることは分かる。本例では 条件付き破壊確率の計算は非線形不規則振動解析を含んでおり，そ の導関数は求められず，拡張FORMを適用することは難しい。そこ
でサンプリング数を5000と設定し, Monte-Carloシミュレーションを 行った。Monte-Carlo法の解析結果をTable 4に示しており, 本手法で 得られた結果がMonte-Carlo法の結果に一致しており，精度が良いこ とがわかる。なお，設計点については， $x_{1}$ は初期值からほとんど変 化していないが， $x_{2}$ はかなり変化しており，初期剛性より降伏強度 に含まれている不確定性が信頼性解析結果に大きく影響を与えるこ とがわかる[5]。

次に限界状態曲面を考察する。 $x_{1}, x_{2}$ をそれぞれ0.7から1.3まで変 化させ，得られた 5 階の層間変位最大応答の平均值をFig.4に示す。 また，対応する式(9)の限界状態曲面はFig.5に示す。Fig.4と Fig.5に より，最大応答の平均值にはかなりの変化するが, 対応する限界状

Table 4 Structural Parameters and Computational Results

\begin{tabular}{|c|c|c|c|c|c|c|c|c|c|c|c|c|c|c|c|c|c|}
\hline \multicolumn{5}{|c|}{ Structural Parameters } & \multicolumn{7}{|c|}{ Results with Deterministic Parameters } & \multicolumn{6}{|c|}{ Results with Uncertain Parameters } \\
\hline \multirow[t]{2}{*}{ 階 } & \multirow{2}{*}{$\begin{array}{l}\text { 階高 } \\
\mathrm{cm}\end{array}$} & \multirow{2}{*}{$\begin{array}{c}\text { 重量 } \\
t \\
\end{array}$} & \multirow{2}{*}{$\begin{array}{c}\text { 初期剛性 } \\
t / c m \\
\end{array}$} & \multirow{2}{*}{$\begin{array}{c}\text { 強度 } \\
t \\
\end{array}$} & \multirow{2}{*}{$\begin{array}{l}\mu \text { of } \\
R_{\max }\end{array}$} & \multirow{2}{*}{$\begin{array}{l}\text { Duct. } \\
\text { Ratio }\end{array}$} & \multirow{2}{*}{$\begin{array}{c}\sigma \text { of } \\
R_{\max }\end{array}$} & \multirow[t]{2}{*}{$P_{f}$} & \multirow{2}{*}{\multicolumn{3}{|c|}{$\begin{array}{c}\text { Graphics of } \\
R_{\max }\end{array}$}} & \multirow{2}{*}{\multicolumn{2}{|c|}{$\begin{array}{c}\text { Design Point } \\
x_{1} \quad x_{2}\end{array}$}} & \multicolumn{2}{|c|}{ Proposed Method } & \multicolumn{2}{|c|}{ Monte-Carlo } \\
\hline & & & & & & & & & & & & & & & $P_{F}$ & $\beta$ & $P_{F}$ \\
\hline 15 & 400 & 397 & 404 & 490 & 2.30 & 1.90 & 0.17 & 0.0 & 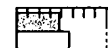 & IITाTा? & & $x$ & $x$ & $\dot{x}$ & $x$ & $x$ & 0 \\
\hline 14 & 400 & 1278 & 615 & 1909 & 6.16 & 1.98 & 0.46 & 0.0 & 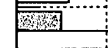 & & -1 & $x$ & $x$ & & $x$ & $x$ & 0 \\
\hline 13 & 335 & 1909 & 1084 & 3044 & 7.62 & 2.71 & 0.60 & 0.0 & 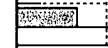 & & 7 & $x$ & $x$ & & $x$ & 3.66 & $1.3 \times 10^{-4}$ \\
\hline 12 & 310 & 1400 & 1429 & 3739 & 7.47 & 2.85 & 0.61 & 0.0 & - & W... & -1 & $x$ & $x$ & & $x$ & 3.28 & $5.3 \times 10^{-4}$ \\
\hline 11 & 310 & 1386 & 1687 & 4216 & 7.52 & 3.01 & 0.63 & $1.2 \times 10^{-7}$ & Fis & $\ldots$ & -1 & $x$ & $x$ & & $x$ & 2.93 & $1.7 \times 10^{-3}$ \\
\hline 10 & 310 & 1465 & 1979 & 4464 & 7.68 & 3.40 & 0.66 & $1.0 \times 10^{-5}$ & & & - & 1.01 & 0.68 & 2.40 & $08.2 \times 10^{-3}$ & 2.40 & $8.3 \times 10^{-3}$ \\
\hline 9 & 310 & 1624 & 2200 & 5271 & 7.25 & 3.03 & 0.64 & $2.9 \times 10^{-7}$ & - & & 7 & $x$ & $x$ & & $x$ & 2.83 & $2.4 \times 10^{-3}$ \\
\hline 8 & 310 & 1595 & 2488 & 5665 & 7.09 & 3.11 & 0.63 & $9.5 \times 10^{-7}$ & & & - & $x$ & $x$ & & $x$ & 2.71 & $3.4 \times 10^{-3}$ \\
\hline 7 & 310 & 1615 & 2889 & 6141 & 6.52 & 3.07 & 0.59 & $6.5 \times 10^{-7}$ & & …… & -1 & $x$ & $x$ & & $x$ & 2.77 & $2.8 \times 10^{-3}$ \\
\hline 6 & 310 & 1961 & 3347 & 5669 & 7.16 & 4.23 & 0.65 & $2.0 \times 10^{-3}$ & 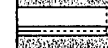 & we & & 1.04 & 0.77 & 1.54 & $46.1 \times 10^{-2}$ & 1.63 & $5.2 \times 10^{-2}$ \\
\hline 5 & 450 & 3546 & 2999 & 5953 & 9.60 & 4.84 & 0.88 & $1.7 \times 10^{-2}$ & 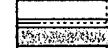 & & يج & 1.02 & 0.82 & & $4 \quad 0.1268$ & 1.16 & 0.1236 \\
\hline 4 & 450 & 4613 & 2909 & 7224 & 10.26 & 4.13 & 0.94 & $1.5 \times 10^{-3}$ & E........ & & ] & 1.01 & 0.76 & 1.63 & $35.1 \times 10^{-2}$ & 1.62 & $5.2 \times 10^{-2}$ \\
\hline 3 & 500 & 5802 & 2803 & 8735 & 11.22 & 3.60 & 1.03 & $8.0 \times 10^{-5}$ & E............ & & & 1.02 & 0.70 & 2.08 & $81.9 \times 10^{-2}$ & 2.07 & $1.9 \times 10^{-2}$ \\
\hline 2 & 400 & 7593 & 3625 & 9922 & 10.16 & 3.71 & 0.91 & $1.3 \times 10^{-4}$ & 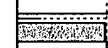 & & - & 1.04 & 0.72 & 1.98 & $82.4 \times 10^{-2}$ & 2.00 & $2.3 \times 10^{-2}$ \\
\hline 1 & 475 & 6007 & 4507 & 10330 & 8.97 & 3.91 & 0.77 & $3.2 \times 10^{-4}$ & $\begin{array}{lll}0 & 4\end{array}$ & 8 & & 1.01 & 0.72 & 1.84 & $43.3 \times 10^{-2}$ & 1.82 & $3.4 \times 10^{-2}$ \\
\hline
\end{tabular}

Note:

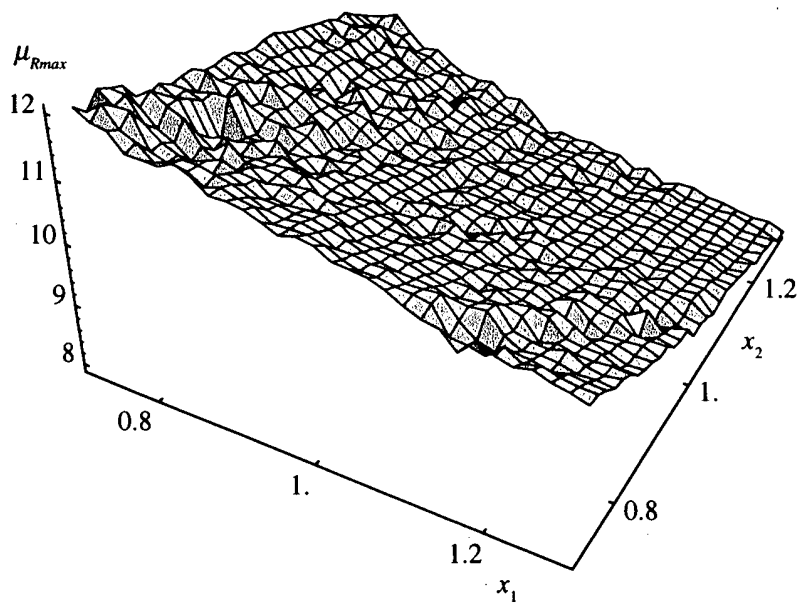

Fig.4 Response Surface of the Mean Maximum Deformation

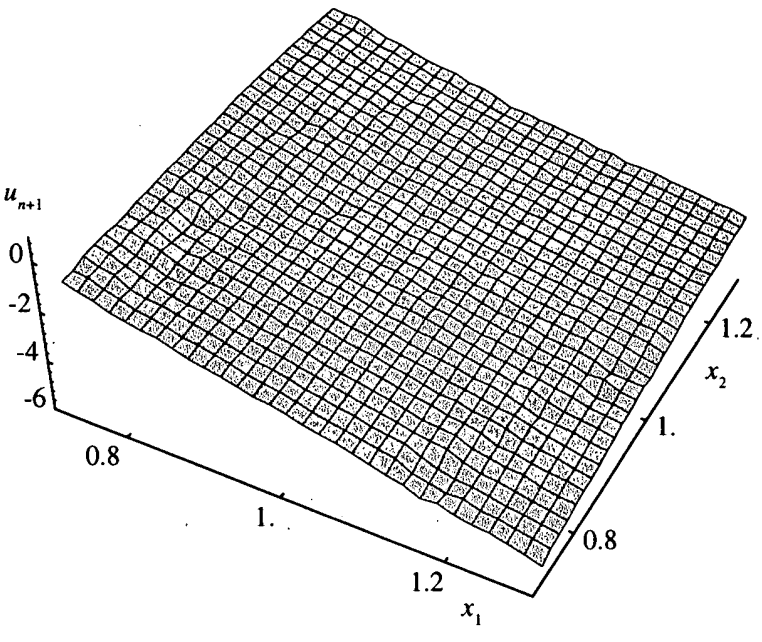

Fig.5 Limit State Surface Expressed by Eq. 12 


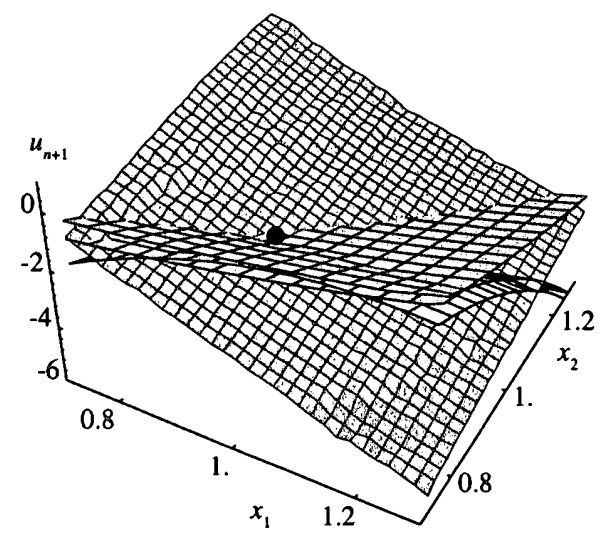

Fig.6 Response Surface with $\delta=0.4 \sigma$

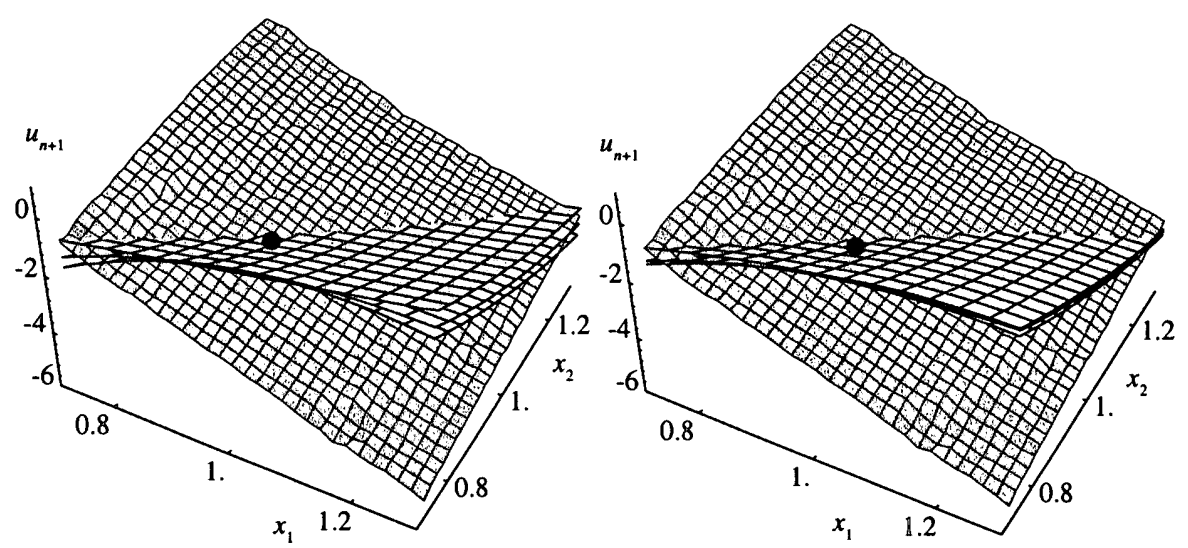

Fig.7 Response Surface with $\delta=0.8 \sigma$
Fig. 8 Response Surface with $\delta=1.2 \sigma$
態曲面にはそれほど変化が見られない。拡張FORMは大きく変化す る応答変数を含む限界状態を緩やかにすることがわかる。

解析過程でのResponse Surfaceを考察するために 3 回の繰り返しで 得られたResponse SurfaceをFig.6に示す。困中黒点はこの問題の設 計点である。この図により, 各回の繰り返しで得られたResponse Surfaceはそれぞれ異なっているが, 全てのResponse Surfaceは設計 点または設計点の近くを通ることがわかる。Response Surfaceは真の 限界状態曲面とはかなり差があるが, 設計点のまわりで二つの曲面 が交差し，ほほ同じ信頼性指標を持っている。さらに, 実験点の違

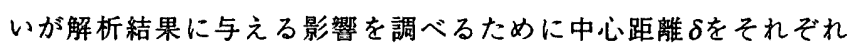
$0.4 \sigma, 0.8 \sigma, 1.2 \sigma$ として解析し, 得られたResponse Surfaceをそれぞれ Fig.6, Fig.7, Fig.8に示す。対応する信頼性指標は $\beta=1.1422,1.1418$, 1.1359である。これらの結果によると，反の違いにより，得られた Response Surfaceがかなり異なってはいるが，对応する信頼性指標は ほほ同じである。

\section{5.おわりに}

本論文では, Response Surface Approach で拡張FORMにおける限 界状態関数を近似し, パラメータの不確定性を考虑できる動的信頼 性評価法の開発を試みており，以下の結果が得られた。

(1) 解析手法では，条件付き破壊確率が不確定性を有するパラメー 夕に対する感度解析が必要はなく，パラメー夕の不確定性を考虑す る複雑な構造の動的信頼性評価に用いることができる。

(2)既存の動的信頼性解析プログラムの利用し, 確定的パラメータ を用いた条件付き破壊確率のわずかな繰り返し計算だけで，十分な 精度を得ることができる。

(3)条件付き確率変数 $P_{\Omega}(\mathbf{X})$ が0または0に近い值になる時，解析が 不可能になることが解析手法の一つの欠点である。しかし，このよ うな限界は実用上には問題がないと考えられる。

\section{参考文献}

[1] Wen, Y.K. \& H-C., Chen, "On Fast Integration for Time Variant Structural Reliability", Probabilistic Engineering Mechanics, Vol.2, No.3, 1987.

[2]Der Kiureghian, "Measures of Structural Safety Under Imperfect States of Knowledge", ASCE, ST 5/7, Vol 115, 1989.

[3] Balendra, T. \& Y.P., Teo, Time Variant Reliability of Linear Oscillator Consid- ering Uncertainties of Structures and input model Parameters, Probabilistic Engineering Mechanics, Vol.6, No.1, 1991.

[4] Zhao, Y.G. \& J.R., Jiang, An Advanced First Order Second Monment Method, Earthquake Engineering and Engineering Vibration, Vol 12, No. 4, 1992(in Chinese).

[5] 小野徹郎, 趙 衍㓮, 石井 清, 井戸田秀樹, パラメータの不確定性を 考䉥した構造信頼性解析, 構造工学論文集, Vol 41B,pp159-164, 1995.3 [6] Zhao, Y.G. \& J.J., Sun, On dynamic Sensitivity Aanlysis of Structures, Earthquake Engineering and Engineering Vibration, Vol 11, No. 4, 1991 (in Chinese). [7] Wong, F.S., Slope Reliability and Response Surface Method, J. Geotechnical Engineering, ASCE, Vol.111, No.1, pp32-53,1985.

[8] Bucher, C.G., Y.M.,Chen, G.I., Schueller, Time Variant Reliability Analysis Utilizing Response Surfces Approach, P. Thoft-Christensen, ed., Reliability and Optimization of Structural System '88, Springer, Berlin, 1989, pp1-14.

[9] Bucher, C.G. \& U., Bourgund, A Fast and Efficient Response Surface Approach for Structural Reliability Problems, Structural Safety, Vol. 7, pp57-66, 1990.

[10] Rajashekhar, M.R. \& B.R., Ellingwood, A New look at the Response Surface Approach for Reliability Analysis, Structural Safety, Vol.12, pp205-220, 1993.

[11] Liu, Y.W. \& F., Moses, A Sequential Response Surface Method and Its Application in the Reliability Analysis of Aircraft Structural Systems, Structural Safety, Vol.16, pp39-46, 1994.

[12] 小野徹郎, 趙 衍剛, 二次関数の限界状態に対するFORM信賴性指標 の検討, 構造物の安全性及び信賴性, Vol.3, A-93, JCOSSAR'95.

[13] Wen, Y.K., Equivalent Linearization for Hysteretic Systems Under Random Excitation, J. Appl. Mech., Vol 47, No. 1, 1980.

[14] Jiang J.J. and Q.N., Lu, Stochastic Seismic Response Analysis of Hysteretic MDF Structures Using Mean Response Spectra, Earthquake Engineering and Engineering Vibration, Vol 4, No. 4, 1984(in Chinese).

[15] Sun, J.J. and J.J., Jiang, Stochastic Seismic Response and Reliability Analysis of Hysteretic Frame-Shear Wall Structures, Earthquake Engineering and Engineering Vibration, Vol 12, No. 2, 1992(in Chinese).

[16] 建築耐震設計における保有耐力と変形性能, 日本建築学会, 1990.10.

[17] 建築物荷重指針・解説, 日本建築学会, 1993.6 .

[18] 小野徽郎, 井戸田秀樹, 河原弘明, 高次積率を用いた銅圧樎材および 曲げ材の抵抗強度に関する統計論的研究, 日本建築学会構造系論文報告 集, 第370号, 1986.12. 